DOI: https://doi.org/10.34069/AI/2021.39.03.17

\title{
Covid pandemic and amendments to Employment law in Ukraine and Europe
}

\section{Пандемія коронавірусу та зміни в трудове право в Украӥні та Європі}

Received: April 5, 2021

Recived: April 5,2021

\begin{abstract}
The COVID - 19 coronavirus pandemic has demonstrated the unwillingness of many spheres of public life to respond adequately to critical situations. And first, it concerned the legal regulation of labour relations, which has undergone quite fundamental changes, which today form a new, more modern system of functioning of the labour market. Businesses may indeed violate employees' rights and protection from completely unwarranted resignation and even to gain adequate justice and national government aid. Workers with informal employment agreements, and limited access to healthcare and social protection before the pandemic, are particularly at risk now.

The present research paper describes the relevant questions in Employment law, which relate to the Covid-19 pandemic in Ukraine and Europe.

Some workers' right to engage in work may disproportionately suffer due to the restrictions in place. These include parents of young children and single parent families, employees with health issues and disabilities, and migrant workers transported to work in agriculture or to provide social care. There is also concern about fair and just working conditions.

This paper aims to answer the main questions connected with the Employment law in Covid time by conducting a literature review covering legal amendments to national and international legislations and examining the foreign practice related to employees' rights connected with the
\end{abstract}

Accepted: May 4, 2021

Written by:

Kudriavtsev Igor Volodymyrovych ${ }^{62}$ https://orcid.org/0000-0003-1352-4906

Kotova Liubov Vyacheslavna ${ }^{63}$ https://orcid.org/0000-0002-2437-3624

Arsentieva Olena Serhiivna ${ }^{64}$

https://orcid.org/0000-0001-7959-8524

${ }^{62} \mathrm{PhD}$ of Law, Associate Professor of the Department of Law, Volodymyr Dahl East Ukrainian National University (Severodonetsk, Ukraine)

${ }^{63} \mathrm{PhD}$ of Law, Associate Professor, Associate Professor of the Department of Law, Volodymyr Dahl East Ukrainian National University (Severodonetsk, Ukraine)

${ }^{64}$ Ph.D., Associate Professor, Dean of the Faculty of Law of S Volodymyr Dahl East Ukrainian National University (Severodonetsk, Ukraine)

\begin{abstract}
Анотація
Пандемія коронавірусу COVID - 19 продемонструвала небажання багатьох сфер суспільного життя адекватно реагувати на критичні ситуації. I в першу чергу це стосується правового регулювання трудових відносин, яке зазнало досить фундаментальних змін, оскільки реалії сьогодні формують нову, більш сучасну систему функціонування ринку праці. Бізнес може дійсно порушувати права працівників, а громадяни все частіше потребують захисту від абсолютно необгрунтованої відставки та навіть отримання належної справедливості та державної допомоги. Спостерігаємо, що зараз особливо схильні до ризику працівники, які мають неформальні трудові угоди та обмежений доступ до охорони здоров'я та соціального захисту.

У цій статті описано відповідні проблеми трудового законодавства, які пов'язані 3 пандемією Covid-19. Оскільки права деяких робітників на зайняття працею може непропорційно потерпати через наявні обмеження. Сюди входять такі категорії людей як: батьки маленьких дітей та неповні сім'ї, працівники, що мають проблеми зі здоров'ям та інвалідністю, а також працівники-мігранти, перевезені на роботу в сільське господарство або заклади надання соціальної та медичної допомоги.

Стаття має на меті відповісти на основні питання, пов'язані 3 трудовим законодавством у час пандемії Covid-19 шляхом здійснення детального огляду змін до законодавства та наукової літератури, що охоплює аналіз законодавчих змін до національного та міжнародного законодавства,
\end{abstract}




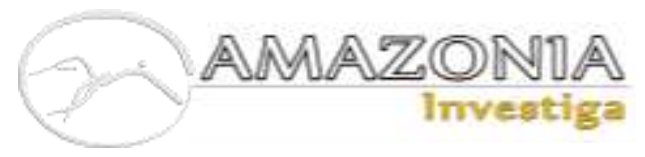

labour restrictions in the time of pandemic.

Keywords: Covid restrictions, Employment law, employees' rights, EU Employment law, Ukrainian Employment law.

\section{Introduction}

Introduction of quarantine and related restrictive measures due to the COVID-19 pandemic has become a real challenge for society. The topic of protection of labour rights during the quarantine period is extremely relevant. The new economic crisis that has begun with the coronavirus is having a profound effect on all processes in public life: the economy, business, manufacturing and, unfortunately, human rights. The purpose of the article is to highlight the features of the legal regulation of labour relations during the introduction of the Ukrainian government quarantine. We also focus on the main issues that the employer should pay attention to in order to improve the working conditions of its employees during the quarantine period.

The Covid-19 pandemic and the introduction of restrictive measures have led to the emergence of new, previously unknown to Employment law, mechanisms for working in self-isolation (first of all, remote work outside the office for workers with previously non-remote and non-regulated labour legislation working conditions during the period imposed by presidential decrees the regime of "non-working days". Thus, the contradictions between the real processes in the labour sphere during the epidemic and national Employment law, in particular, the forms of employment and working time established by it, were revealed.

The main solutions for Employment law in the time of Covid-19 to optimize work of employees are following: downtime, downsizing, and parttime transfer. The principles of behavior of employers and employees in the conditions of quarantine measures are not specifically prescribed in the current national law (Ukraine).

The article discusses the practical questions, which arise in the prism of the determination Covid-19 restrictions and measures taken by different National and European institutions related to Employment law. Most of the issues to be examined in this research are related to examine international laws and its amendments а також вивчення зарубіжної практики, що стосується прав працівників в умовах пандемії.

Ключові слова: Covid -19, обмеження у зв'язку з коронавірусом, трудове право, права працівників, трудове право України, трудове право Європейського Союзу.

connected with the protection of employees' rights in the time of coronavirus pandemic.

\section{Methodology}

The subject of the study, its purpose and objectives, the specifics of the object and the subject determined its methodological basis. The choice of research methods was determined by the purpose of the study, which is to study the essence of Covid-19 measures and its restrictions regarding Employment law in the time of pandemic.

To achieve this goal, the following tasks were solved: to analyze national and European legislation related to Covid-19 labour regulations, to study experience of foreign countries in the field of employees' law, to provide recommendations on optimization of Employment law in Ukraine.

The scientific validity of the formulated conclusions is achieved by using the basic methods of scientific knowledge such as statistical, hermeneutical, general scientific, formal legal and special legal methods.

The statistical method was used to summarize international legislation related to Covid-19 updates.

The formal legal method was used for the legal analysis of international normative legal acts which regulate Employment law in Ukraine and Europe.

Also, the hermeneutical method promoted translation and a common understanding of the of international Employment law and its mechanism in protection of employees' rights.

\section{Research background}

Like in many countries, the coronavirus has had an immense impact on EU and Ukrainian society. As statistic data shows, because of the economic crisis created by the pandemic, almost 1.6 billion informal economy workers (representing the 
most vulnerable in the labour market), out of a worldwide total of two billion and a global workforce of 3.3 billion, have suffered massive damage to their capacity to earn a living. This is due to lockdown measures and/or because they work in the hardest-hit sectors.

Worldwide, more than 436 million enterprises face high risks of serious disruption. These enterprises are operating in the hardest-hit economic sectors, including some 232 million in wholesale and retail, 111 million in manufacturing, 51 million in accommodation and food services, and 42 million in real estate and other business activities (OECD report, 2020).

However, it is worth noting that the scientific community already devoted enough time to study the main options for the development of labour relations during the quarantine period.

The study of scholars' works reveal that at the moment there is a large number of researches that discuss some aspects of covid situation and pandemic restrictions especially Lina Vyas \& Nantapong Butakhieo (2021), describing the impact of working from home during COVID-19 on work and life domains, Adam Sagan \& Christian Schüller (2020), developing the Covid19 and Employment law discussions in Germany, Tatiana Sachs (2020), describing Covid-19 and Employment law in France, Lucia Svabova \& Zdenko Metzker \& Tomasz Pisula (2020) discussing the evelopment of unemployment in Slovakia in the context of the Covid-19 pandemic, Suder S. researching the question of personal data during the Covid-19 (2020), Stephen Blumenfeld \& Gordon Anderson \& Val Hooper (2020) with the article "Covid-19 and Employee Surveillance”, T, Gyulavári (2020) describing the experience of Hungary in the field of Employment law and Hendrickx F, Taes S, Wouters M. described main amendment to Belgium legislation in the time of Covid-19 (2020).

\section{Results and discussion}

\section{Covid-19 pandemic situation in Ukraine}

Ukrainian experience shows that as a rule, an employee may not be dismissed except on grounds expressly provided by law. According to the provisions of the Labour Code of Ukraine, quarantine or restrictive measures are not grounds for dismissal OECD report. (2020).
However, regardless of the introduction of quarantine or restrictive measures, the employment contract may be terminated at the initiative of the employer in the cases specified in Articles 40 and 41 of the Labour Code of Ukraine (Labour Code).

For example: liquidation of the enterprise, reduction of the number or staff (paragraph 1, part 1 of Article 40 of the Labour Code of Ukraine), incompatibility of the employee with the position due to insufficient qualifications or health (paragraph 2, part 1 of Article 40 of the Labour Code of Ukraine), absenteeism (paragraph 4, part 1 of Article 40 of the Labour Code of Ukraine) and other similar cases specified by law (Law No. 322-VIII, 1971).

Also, if the employer and the employee agree, the employment contract may be terminated at any time by agreement of the parties (Article 36 of the Labour Code of Ukraine) or terminated at the discretion of the employee (Article 38 of the Labour Code of Ukraine). However, I draw your attention to the fact that the employee cannot be forced to resign of his own free will. The right to dismiss on such grounds depends solely on the employee's wishes, and this ground cannot be enforced (Law No. 322-VIII, 1971).

The law does not provide for any additional grounds for dismissal of an employee during the quarantine period or restrictive measures.

That is, if the grounds for dismissal do not comply with the provisions of the law and / or the employer does not follow the procedure for dismissal of the employee, such dismissal will be considered illegal.

If your employer informs you that your job is being quarantined, he or she must either offer you another job or give you at least two months' notice of dismissal, and pay you everything you need, including unused leave. Both in the event of redundancy and in the event of closure, you have the right to apply for unemployment benefits while you are looking for a new job.

Also, in connection with the cancellation of the transport service, the question arises, can the employer dismiss the employee for absenteeism caused by the fact that you could not get to work? In accordance with paragraph 4 of Part 1 of Art. 40 of the Labour Code of Ukraine, the employment contract may be terminated by the owner or his authorized body in case of absence (including absence from work for more than three hours during the working day) without 
good reason. The law does not clearly define which reasons are valid, but according to established practice, a valid reason is the objective inability to get to work.

Today, there are four options for what to do if physical presence in the workplace is impossible. Accordingly, under such conditions, the owner (manager) of the enterprise, depending on the specific circumstances of the case and economic considerations, may resort to the following steps OECD report. (2020).

1. Temporary transfer of an employee to another job with his consent for a period of up to one month. Temporary transfer of an employee to a job not stipulated in the employment contract is allowed only with his consent. Without the employee's consent, only a temporary transfer to another job for up to one month is allowed, unless it is contraindicated for the employee's health condition and only to prevent or eliminate the consequences of natural disasters, epidemics, industrial accidents, etc.

2. Introduction of idle mode at the enterprise. Simple is a stoppage of work caused by the lack of organizational or technical conditions necessary to perform the work, unavoidable force, or other circumstances. In case of downtime, employees may be transferred with their consent to another job at the same company for the entire period of downtime or to another company, but in the same area for up to one month. At the time of downtime (not due to the fault of the employee) the company has the right to reduce the wages of employees, compared to the period of normal operation of the company, at least $2 / 3$ of the salary. Also, the company has the right not to pay bonuses and surcharges to the minimum wage (subject to a full month of downtime). However, payments that are mandatory and causally linked to salary, such as degree, seniority, rank, are retained. Consent or any other statement from the employee is not required for registration. The company draws up a simple relevant order.

3. Transfer of employees to the mode of remote work (i.e. work from home). If the employee works remotely, the employer must enter a written employment contract with him. Exception - the employer introduces a flexible mode of work or remote work at the time of the threat of an epidemic, pandemic. In this case, an employer's order is sufficient. The total time of remote work should not exceed the standards. Such work should be paid in the same way as performed directly at the enterprise or in the office.

However, what to do to a person at a state-owned enterprise who can and wants to work remotely, but is not allowed by the management? Such a person has the right to write an application for remote work, but the satisfaction or rejection of such an application depends solely on the wishes of the employer.

Also, recent amendments to the legislation (Law of Ukraine "On Amendments to Certain Legislative Acts of Ukraine Aimed at Providing Additional Social and Economic Guarantees in Connection with the Spread of Coronavirus" (COVID-19) of March 30, 2020 № 540-IX) have been repealed. Mandatory requirement to comply with the internal agenda and included a new article: on flexible working hours. This means that it is determined not in a day, but in two weeks, a month, etc., depending on the grounds. That is, no one stands over you with a watch every day and does not keep track of how much time you spent at work. The employee determines when he works out his norm, when he takes a break for rest or lunch. This flexible regime cannot change your pay or your employment rights (Law No. 540-IX, 2020).

4. Providing an employee with regular annual, additional leave (if there are grounds established by law) or leave without pay. Annual regular and additional leave is granted for a specified period at the request of the employee. According to Art. 26 of the Law "On Leave" an employee may be granted leave without pay for the entire period of quarantine. It is important to remember that whether or not to take leave is an employee's right, not an obligation, and cannot be enforced. On the other hand, keep in mind that the employee's desire to go on vacation without pay for the period of quarantine does not guarantee $100 \%$ of its provision by the employer. After all, the latter has the right both to grant such leave and to refuse to grant it. Unpaid leave is also compulsory for persons who take care of a child under the age of 14 (one of the parents, grandparents, other relatives, persons who have child, etc.).

To summarize, the Verkhovna Rada of Ukraine adopted the Law of Ukraine "On Amendments to Certain Legislative Acts Aimed at Providing Additional Social and Economic Guarantees in 
Connection with the Spread of Coronavirus Disease (COVID-2019)". This Law amends the Labour Code of Ukraine, the Law of Ukraine "On Employment", according to which employees during quarantine have the right to:

- $\quad$ work on the terms of remote (home) work (Article 60 of the Labour Code of Ukraine).

Remote (home) work is a form of work organization when work is performed by an employee at his place of residence or in another place of his choice, including with the help of information and communication technologies, but outside the employer's premises.

In the case of remote (home) work, employees distribute working time at their discretion, they are not subject to the rules of internal labour regulations, unless otherwise provided in the employment contract. In this case, the total duration of working hours may not exceed the rules provided for in Articles 50 and 51 of this Code. Article 50 of the Labour Code establishes the normal working hours of employees, which may not exceed 40 hours per week. During the period of introduction of quarantine and application of restrictive measures, the condition of remote (home) work is established in the order (order) of the employer, with which the employee must be acquainted.

- to work on the conditions of flexible working hours (Article 60 of the Labour Code of Ukraine).

By agreement between the employee and the employer, a flexible working hour may be established for the employee for a definite period or indefinitely, both when hiring and later.

Flexible working hours are a form of work organization that allows the establishment of a work schedule that is different from the rules of internal labour regulations, subject to compliance with the established daily, weekly or for a certain accounting period (two weeks, months, etc.) working hours.

Flexible working hours can include:

1) a fixed time during which the employee must be present at the workplace and perform their duties; in this case, the division of the working day into parts may be envisaged.

2) variable time, during which the employee at its discretion determines the periods of work within the established norm of working hours.

3) break time for rest and meals.

Accounting for working time is provided by the employer. Flexible working hours, as a rule, are not applied at continuously operating enterprises, institutions, organizations, multi-shift work, as well as in other cases due to the specifics of the activity, when the employee requires his presence in clearly defined rules of internal labour schedule of working hours (trade, consumer services, loading and unloading, transport, etc.) or when such a regime is incompatible with the requirements for safe working conditions.

- for remuneration in full and within the time limits specified in the employment contract, for the performance of remote (home) work or work on a flexible working hour (Article 60 of the Labour Code of Ukraine).

Performing remote (home) work or the use of flexible working hours does not entail any restrictions on the scope of labour rights of employees.

- to pay for downtime during the period of quarantine at the rate of not less than twothirds of the tariff rate set for the employee category (salary) (Article 113 of the Labour Code of Ukraine).

- for unpaid leave for the period of quarantine (Article 84 of the Labour Code of Ukraine, Article 26 of the Law of Ukraine "On Leave")

Please note that such leave is granted with the consent of the parties to the employment contract. If the employee does not wish to take leave without pay for the period of quarantine, the employer has no right to require him to write an application for such leave.

In addition, it should be borne in mind that in accordance with paragraph 3-1 of the first article 25 of the Law of Ukraine "On Holidays" mother or other person (father of the child, grandmother, grandfather or other relatives who actually care for the child, adopted or has taken custody of a child, one of the adoptive parents or foster parents) is granted unpaid leave to care for a child under 14 years of age for the period of quarantine. Such leave is granted at the request of the employee. That is, the employer has no right to deny the specified employees the granting of the specified leave. 
Employees also have the right to use during the quarantine period:

- unused paid annual main and additional leave, the procedure for granting which is defined in Article 10 of the Law of Ukraine "On Leave" (Law No. 504/96-BP, 1996):

- social additional leave for employees who have children or an adult child - a person with a disability from childhood of subgroup A I group (Article 19 of the Law of Ukraine "On Leave").

- for partial unemployment benefits for the period of measures to prevent the occurrence and spread of coronavirus disease (COVID19), provided by the quarantine established by the Cabinet of Ministers of Ukraine (Articles 47, 471 of the Law of Ukraine "On Employment").

Partial unemployment benefits are provided by employment centers to insured persons in case they lose part of their salary due to forced reduction of working hours due to suspension (reduction) of activities due to measures to prevent the occurrence and spread of coronavirus disease (COVID-19), provided by quarantine, established by the Cabinet of Ministers of Ukraine, at the request of the employer for its payment to employees.

The amount of partial unemployment benefits is provided to employers from small and medium enterprises during the period of measures to prevent the occurrence and spread of coronavirus disease (COVID-19), provided by the quarantine established by the Cabinet of Ministers of Ukraine, and in case of arrears of arrears wages and payment of a single contribution to the obligatory state social insurance.

Reports also arose of some employers not heeding government requirements to contain the virus and putting their workers at risk of infection by not respecting physical distancing rules. Some governments also relaxed or suspended rules on working time restrictions. This resulted from the additional pressure on sectors like health and social care, and food production and distribution, to tackle the pandemic.

Intra-EU labour mobility is centered on matching labour supply to demand, as a mechanism to sort out inefficiencies in national labour markets. Relative to sourcing non-EU migrants, using EU free movers to address labour shortages significantly reduces costs for public administrations and employers in the countries of destination.

\section{Covid-19 pandemic situation in Europe}

As for the experience of foreign countries, a significant part of them developed business support programs, programs employer support, even compensation programs employees of a certain part of the salary in connection with the predicament in which all found themselves without exception. Also, some countries have decided to partially cover costs for payment of wages from the state budget. In these countries, the state compensates the employer for $50-80 \%$ of the employee's salary. In particular, in Slovakia, a detailed program to support employers and employees. One of the most striking provision of this program is that the state will compensate employees of those companies that through quarantine and the epidemic were forced to close temporarily, about $80 \%$ of wages in order to support the business (i.e. the employer will only have to pay $20 \%$ of salary) (Mangan, 2020).

Very important question is also determined during distant work is personal data and security of legal entities and it's employees. As Suder S. described, many companies in EU developed their own identification and verification system and started use personal data more careful (Suder, 2020).

In Luxemburg, the Government has declared strict containment of the population since 16 March 2020. A law of 24.03.2020 has extended the state of emergency for a period of three months.

Every establishment, every commercial and artisanal activity open to the public, have been forced to shut down, under penalty of a fine of up to EUR 4,000, with exception to:

- essential activities (i.e. of vital interests of the population and the country),

- those mainly selling food products, health and sanitary products, fuel and petrol stations,

- those providing for telecommunication and postal services,

- financial and insurance institutions, and

- those able to provide for take-out, drive-in and home delivery services.

In Luxemburg, income support measures are grouped into three main categories: those 
applicable to employees and assimilated; those applicable to the self-employed; and those applicable to unemployed people (Ratti, 2020). According to Article L. 511 of the Luxembourgish Code du Travail, the State reimburses $80 \%$ of salaries for a period up to 1,022 hours per year through the Fonds pour l'emploi, on the condition that the employer continues paying the salaries and does not dismiss the beneficiaries for economic reasons (Article L. 511-3). Before accessing this measure, the employer must inform and consult the staff delegation and the relevant trade unions. The amount of the state reimbursement may not be less than the statutory minimum wage (for non-qualified employees) and has been capped up to $250 \%$ of such minimum wage. Uncertainties still remain over the relationship between the chomage partiel and leave (in particular parental leave). No specific measure has affected the employer's ability to dismiss employees, an exception having been made for those who benefit from chômage partiel schemes. The Government has, instead, adopted the suspension of probationary periods in respect of all locked-down activities and those benefitting from the chômage partiel. (Ratti, 2020).

Accordingly to Italian experience, from a Employment law perspective, the mandatory closure of activities and businesses impacted equally on workers and employers, that were both unable to fulfil their contractual obligations due to the external constraint of the authorities ('factum principis'). Accordingly, unless the employees were sick or in quarantine or unless they kept carrying out their working activities through agile working (see infra), employers were freed from the obligation to pay wages. This explains why the workers employed by the closed businesses (initially in the 'red zone' and later in the whole country) were granted financial aid through the Italian social security system. The legislator opted for an extensive use of the Ordinary Wage Guarantee Fund (Cassa Integrazione Guadagni Ordinaria), which was made available through a simplified and quicker procedure. The maximum duration of financial support due to the Covid-19 emergency was determined to be nine weeks of suspension until August 2020. The latter period was extended to fourteen weeks pursuant to Article 68 (Law Decree No 34, 2020), which also granted four additional weeks of suspension from 1 September 2020 to 31 October 2020 (Biasi, 2020).
In Belgium, legislator amend an additional possibility which postponed the payment deadline for road taxes and immovable withholding tax. Also, Government guarantees on bank loans which may safeguard the employees from leaves (Hendrickx, Taes, \& Wouters, 2020).

Similar to many other European countries, the Irish Government has attempted to address the employment implications of the Covid-19 pandemic through a mixture of income support schemes. Coming with the repercussions of the Great Recession remain in memory and the toll that took on the Irish banking sector, the Government seems to have endeavoured to take an approach that may be more conservative as compared to other EU Member States. (Mangan, 2020).

\section{Conclusions}

One of the consequences of the spread of COVID-19 there have been significant changes in the labour market. While as pays considerable attention to the regulation of labour relations government, government officials are developing a number of mechanisms aimed at resolving conflicts between employees and employers, to protect their legal rights, because each employee must be sure that the risks associated with his work are minimized.

Summing up, it should be noted that considerable attention is paid to the legal aspects of labor protection to regulate the employment relationship between employer and employee in the conditions of remote work.

An example of regulation of labor relations between the main subjects of labor relations, which would allowed to minimize occupational injuries for employees and avoid the risk of attracting the employer to one of the types of legal liability, because on the latter is responsible for meeting all requirements on labor protection. During remote work, employees distribute working hours at their discretion, and the Rules of Internal Labor Regulations do not apply to them. However, the procedure and conditions of flexible working hours are appropriate nevertheless prescribe in the Rules of Internal Labor Regulations in order to minimize cases of neglect by employees of their work responsibilities.

The threat of coronavirus is not a cause for violation labor rights of employees. For those enterprises, institutions or organizations that 


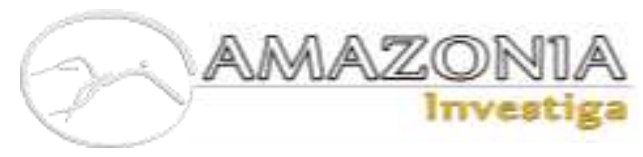

operate continuously in the ordinary regime, employers should create such working conditions on workplace, which must be sufficient to ensure the safety of people.

\section{Bibliography references}

Biasi, M. (2020) Covid-19 and Employment law in Italy. European Employment law Journal, 11(3), 306-313. doi:10.1177/2031952520934569 Blumenfeld, S., Gordon, A. \& Hooper, V. (2020). Covid-19 and Employee Surveillance. New Zealand Journal of Employment Relations. 45, 42-56. 10.24135/nzjer.v45i2.28.

Gyulavári, T. (2020). COVID-19 and Employment law: Hungary. Italian Employment law E-Journal, 13(1S). https://doi.org/10.6092/issn.1561-8048/10793

Hendrickx, F., Taes, S., Wouters, M. (2020) Covid-19 and Employment law in Belgium. European Employment law Journal, 11(3), 276-285. doi:10.1177/2031952520934554

Law Decree No. 34/2020. Official Gazette no. 128 of 19 May 2020 (the "Rilancio Decree"), available at:

https://www.gazzettaufficiale.it/eli/id/2020/05/1 9/20G00052/sg

Law No. 322-VIII/1971. Labour Code of Ukraine, The Verkhovna Rada of the USSR. available at:

https://zakon.rada.gov.ua/laws/show/322-

08\#Text

Law No. 504/96-BP/1996. About holidays. The Verkhovna Rada of Ukraine. On leaves, dated from November 15, 1996, available at: https://zakon.rada.gov.ua/laws/show/504/96$\%$ D0\%B2\%D1\%80\#Text.

Law No. 540-IX/2020. On Amendments to Certain Legislative Acts of Ukraine Aimed at Providing Additional Social and Economic Guarantees in Connection with the Spread of
Coronavirus" (COVID-19). The Verkhovna Rada of Ukraine of March 30, 2020, available at: https://zakon.rada.gov.ua/laws/show/54020\#Text

Vyas, L. \& Butakhieo, N. (2021) The impact of working from home during COVID-19 on work and life domains: an exploratory study on Hong Kong, Policy Design and Practice, 4(1), 59-76, DOI: $10.1080 / 25741292.2020 .1863560$

Mangan, D. (2020). Covid-19 and Employment law in Ireland. European Employment law Journal, 11(3), 298-305. doi:10.1177/2031952520934567

OECD report. (2020). The Covid-19 crisis in Ukraine. Available at: https://www.oecd.org/eurasia/competitivenessprogramme/eastern-partners/COVID-19-

CRISIS-IN-UKRAINE.pdf

Ratti, L. (2020) Covid-19 and Employment law in Luxembourg. European Employment law Journal, 11(3), 314-318. doi:10.1177/2031952520934570

Sachs, T. (2020). Covid-19 and Employment law in France. European Employment law Journal, 11. 203195252093456. $10.1177 / 2031952520934565$.

Sagan, A. \& Schüller, C. (2020). Covid-19 and Employment law in Germany. European Employment law Journal, 11. 203195252093456.

$10.1177 / 2031952520934566$.

Suder S. (2020) Processing employees' personal data during the Covid-19 pandemic. European Employment law Journal. December 2020. doi: $10.1177 / 2031952520978994$

Svabova, L., Metzker, Z., \& Tomasz, P.. (2020). Development of unemployment in Slovakia in the context of the Covid-19 Pandemic. Economic and managerial spectrum, 14, 114-123. 10.26552/ems.2020.2.114-123. 